\title{
Sadwēs, Anāhīd and the Manichaean Maiden of Light ANTONIO PANAINO (Bologna/Italien)
}

It was MARY BOYCE in $1951^{1}$ who first demonstrated the remarkable role attributed to Sadwess in the framework of Iranian Manichaean cosmology. ${ }^{2}$ Parthian Sadwēs [sdwys], corresponding to Pahlavi Sadwēs [stwys], a star name of Avestan derivation (satauuaēsa-, m. 'having hundred servants/slaves'), ${ }^{3}$ appears in fact in the hymn M $741 \mathrm{R}^{4}$ as the seducer of the Male Archons, thus as a divinity playing the role of the Maiden of Light, an evocation of the Third Messenger. The name Sadwēs occurs also in the Parthian ms M 1310/1/, but unfortunately, as noted by SUNDERMANN ${ }^{5}$ without context. Some Manichaean sources such as Kephalaia XCV, ${ }^{6}$ the Middle Persian fragment M $292^{7}$ confirm with regard to the Maiden of Light her function of rain-bringer and distributor, but it is in particular the Sogdian text on The Five Resurrections ${ }^{8}$ (M $140)^{9}$ that states that she performs the third Resurrection 'from rains and clouds, ceaselessly winter and summer, spring and autumn'.

$1 \quad$ 1951, pp. 997-999.

2 The present research belongs to a larger study of the Iranian ancient astral cosmologies, and it has partly benefited of the support deriving from the Project of National Interest (PRIN), entitled "Organizzazione territoriale e ideologia nello stato achemenide: gli insediamenti di Persepoli", directed by Prof. A. V. RosSI (Università di Napoli, l'Orientale), and sponsored by the Italian Ministry of the University. This study is one of many others final results produced by the local Unity of the University of Bologna (Branch of Ravenna).

3 See the discussion concerning the etymology and the identification of this star in PANAINO 1995, pp. 100-101. Satauuaēsa and Sadwēs should correspond to the star Fomalhaut, $\alpha$ Piscis Austrini. It must be noted that the association between Lat. Sanduol and Pahl. Sadwess, suggested by PINGReE, is untenable, as shown by PANAINO (2008; 2009, pp. 97-99). Sanduol does not correspond in the Liber Aristotilis of Hugo Santallensis to Fomalhaut, i.e. Sadwēs, but to Deneb, $\alpha$ Cygni, probably called in Pahlavi Sālār [srd'l]. See Sundermann 2001, I, p. 162, Addendum to the note 187.

4 BOYCE 1951, p. 912; 1975, p. 98-99. Cf. DURKIN-MEISTERERNST 2004, p. 306.

51979, p. 128, n. 187 [= 2001, I, p. 154].

6 See Polotsky/BÖhlig 1940, I, pp. 240-244; GARdner 1995, pp. 246-250; BoyCe 1951, p. 999.

7 BOYCE 1951, ibidem.

8 Ibidem.

9 BOYCE 1960, p. 12. 
As MARY BOYCE underlined ${ }^{10}$ the identification between Sadwēs and the Maiden of Light, ${ }^{11}$ taken as the emanation of the Tertius Legatus (myhryzd in Parthian and myšy byyy in Sogdian, but nryshyzd in Middle Persian and nrysf$y z d$ also in Parthian) ${ }^{12}$ has an earlier and complex background.

We know that already in Avestan literature this star named Satauuaesa- was the most important supporter of Tištriia in the myth of the liberation of the waters. ${ }^{13}$ According to Yt. 8, $9,{ }^{14}$ Satauuaèsa sends the waters, previously liberated by Tištriia from the Sea Vourukaș̌a $(Y t .8,8),{ }^{15}$ towards the seven Karšuuars of the earth, rising as a dispenser of peace to the countries, which will gain good harvest. Then, Satauuaēsa rises from the Sea Vourukaša, when the mists gather on the mountain Us.hindu $(Y t .8,32),{ }^{16}$ and distributes the clouds with the help of the Wind (Vāta), who drives rain, clouds and hail onto the seven Karšuuars $(Y t .8,33) .{ }^{17}$ According to Yt. 13, 43, ${ }^{18}$ the Frauuạšis release Satauuaēsa between heaven and earth, so that this star, just like MiOra in Yt. 10, $61,{ }^{19}$ when he listens to the call (of the worshippers), can fill up the water, make water (i.e. rain) fall and plants grow, for the protection of cattle and human beings and of the Aryan countries as well, but also for the protection of the five kinds of animals and for that of the pious men. The same idea is repeated in Yt. 13, 44, ${ }^{20}$ where Satauuaèsa is the grammatical subject of the sentence. Here the astral divinity is described as advancing throughout heaven and earth with the same positive functions of clouds and distributor of rains.

Furthermore, we must note that Satauuaēsa, as the helper of Tištriia, is mentioned in connection with his role of adversary of the Pairikās, the falling stars or 'starred-worms' (stārō.karama-). ${ }^{21}$ In fact, the reference to such a minor yazata- occurs just after Yt. 8, 8, where the Pairikās are introduced for the first time, but also in connection with Tištriia's main function of enemy of Apaoša, the demon of draught, in the final part of the seventh kardag of the Tištar Yašt, precisely where the myth of the combat between Tištriia and Apaoša is fully described. It is worth mentioning that Satauuaēsa was called raēun $\overline{\bar{a}}$

10 BOyCE 1951, ibidem.

11 See the discussion offered by VAN LINDT (1992, pp. 170-175) about the Maiden of Light, as an emanation of the Third Messenger, to be distinguished from the Maiden of Light, the Living Fire, and (but in a different way), from the Twelve Maidens.

12 GersheVITCH $1967^{2}$, p. 40.

13 PANAinO 1990, pp. 100-101; 1995, p. 93.

14 PANAINO 1990, p. 35.

15 PANAino 1990, p. 34.

16 Panaino 1990, p. 56.

17 PANAINO 1990, p. 57.

18 WOLFF 1910, pp. 235-236; MALANDRA 1971, p. 120.

19 Cf. also Y. 16, 8. See SCHLERATh 1968, II, p. 161; GerSheVitch 1967², pp. 102-103; MALANDRA 1971, p. 189.

20 WOLFF 1910, p. 236; MALANDRA 1971, p. 121.

21 PANAINO 2005. 
xvaranayvhä, i.e. 'bright $x$ varanah-endowed', just like Tištriia, in Yt. $8,32 \mathrm{He}$ is also called stîro 'beautiful' and ramaniuuă 'dispenser of peace' in Yt. 8, 9. Exactly like Mïra in Yt. 10, 61, as we noted before, Satauuaēsa is tat.āpam zauuanō.srūtam taț.āpam uxšiiat.uruuaram (nom. in Yt. 13, 44: taț.āpō zauuanō.srūtō tat. $\bar{p} p \bar{o}$ uxšiiat.uruuarō 'he who can fill up the water when listening to the call [of the worshippers], make the water [i.e. rain] fall and plants grow'). In Yt. 13, 44, Satauuaēsa is again called stīrō 'beautiful', but also bānuuă 'shining' (< bānuuant-) and raoxšñmẵ 'full of light' (< raoxšnzmant-). ${ }^{22}$

The Avestan data regarding Satauuaēsa that can be directly put in connection with the image of the Maiden of Light are many: Satauuaēsa as a star of Tištriia's cycle is directly involved in the process of distribution of clouds and rains, but, in this respect, the yazata- shares with MiOra, who was later identified by Parthian and Sogdian Manichaeans with the Tertius Legatus, some epithets specifically concerning the fall of waters. We may affirm without doubt that Satauuaēsa also played an antidemoniac role, and that his brightness was emphasized in many places. The same characteristic was essential in the case of the Maiden of Light. It is interesting, however, to remark that in M $741 \mathrm{R}$ /3a/ Sadwēs is called rō̌sn [rwšn] 'bright, light', an adjective very fittingly corresponding to raox̌snamant- 'full of light' of Yt. 13, 44.

According to M $741 \mathrm{R} / 4 \mathrm{~b} /$, Sadwēs, who must be the subject of the sentence, 'gives it (i.e. the Light born in the sphere) to the high Powers' (pad ispir

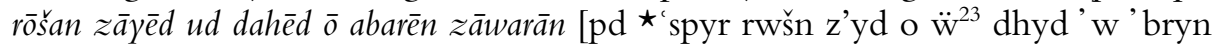
$\left.\left.z^{\prime} w r^{\prime} n\right]\right) .{ }^{24}$ This function played by Sadwees in the seduction of the Demon of Wrath and of the other Archons should not be seen in isolation from the role of this star in the doctrine of the cosmic bonds, which was known in India, and in Iran, both among Mazdeans and Manichaeans, although with (at least in part) different connotations and implications. We cannot ignore that the same elements of Light are referred to in the first verse of this very hymn as bastagān 'the captives', which are released from bondage (band), and that the rest of the fragment belonging to a second hymn concerning Pèsūs is full of references to the same doctrine. I have discussed in details the special implications of this terminology ${ }^{25}$ which includes different doctrines attested in a relevant number of Manichaean texts. From an original model of Indian derivation, which introduced the existence of planetary chords of wind pulled to and fro by demons placed on the lunar nodes, later developed in the framework of the Purānic literature to a kind of mill, where all the astral bodies were kept in

22 MALANDRA 1971, p. 77. Both epithets are hapax legomena.

23 As very kindly Dr. DESMOND DURKIN-MEISTERERnST informs me, the copy of the text in Otani $6208+/ \mathrm{R} / 8 /$ has 'wd; but M 741/R/4b/, which BOYCE was editing has $\ddot{w}$, i.e. the abbreviation for 'wd.

24 BOYCE 1951. p. 912; 1975, p. 98, n. 4.

25 PANAINO 1997, pp. 280-290; 1998, passim. 
motion by wind-ropes attached to the peak of Meru, ${ }^{26}$ the Iranians built up the image of planetary demons taken under control by the Sun and the Moon, as clearly attested in the Zoroastrian sources. ${ }^{27}$ Apparently both Zoroastrians and Manichaeans also accepted the idea of the existence of bounds connecting human souls to the seven planets and the twelve zodiacal constellations, or that of cosmic ropes, which connect heaven and earth. In the Manichaean sources we must note that the planets (named parigann) were represented as bound with cords of the wind, ${ }^{28}$ but the human soul was also fastened by the demoness $\bar{A} z$ to the stars and the planets. For instance, it is by means of such a bond that $\bar{A} z$ would like to direct humans towards sin and badness. ${ }^{29}$ The celestial world is connected to the terrestrial one by means of 'conduits' (called in Coptic lih$m e)^{30}$ and 'roots' (Coptic noune), about which we possess a number of references in Western and Eastern Manichaean and anti-Manichaean sources (Gr. pícal [rhizai], Lat. radices; cf. Panarion, LXVI, 26). ${ }^{31}$ These astral 'links' clearly had ambiguous functions, because they played at the same time a mechanical role such as that of making the cosmic sphere rotate, and a demonic function such as that of pouring iniquity on the earth (so particularly the third lihme), but also took the demons under control. In addition, some of them were also attached by $\bar{A} z$ to the souls of human beings. A comparable image of the planetary demons is clearly documented in Mandaean literature, particularly in the Ginz $\bar{a}^{32}$ In the Ethiopic version of Henoch [XVIII, 13-16, XXI, 3-6], the seven stars, probably the planets, were bound, and the astral bodies can turn thanks to the force of the winds.

In this particular framework Sadwēs also plays his own role, because he was appointed as the General of the Southern quarter of the heaven ${ }^{33}$ and, thus, became the direct antagonist of Anāhīd (i.e. Venus), ${ }^{34}$ the planetary demon bound to the chariot of the Sun. Furthermore, the star Sadwès is sometimes quoted in Pahlavi literature with reference to the bonds that link it to the homonymous Sea Sadwēs. ${ }^{35}$

It is clear that the direct antagonism between the star Sadwēs and the planetary demon Anāhīd, as developed in the Zoroastrian milieu, was essential for

26 PANAINO 1998, pp. 52-57, passim.

27 Ir.Bd. VA, 8 (cf. PAKZAD 2005, p. 79); see MACKENZIE 1954, p. 516.

28 M 178; HENNING 1948, pp. 312-313.

29 M 7982, 7983, ANDREAS/HENNING 1932, pp. 196-199; cf. PANAINO 1998, pp. $93-$ 104.

30 See Panaino 1998, pp. 105-129. Cf. also Demaria 1998.

31 RigGi 1967, pp. 118-125.

32 LidZBARSKi 1925, pp. 103, 97, 9-34; PANAINO 1998, pp. 131-140.

33 Ir.Bd. II, 5 (cf. PAKZAD 2005, p. 37); see HENNing 1942, p. 231. Cf. PANAinO 1999.

34 Ir.Bd. VA, 3 (cf. PAKZAD 2005, p. 78); see MACKenZIE 1954, p. 515.

35 PANAINO 1998, pp. 79-80. The mention of the star and of the Sea Sadwēs occurs in the Wizìdagìha $\bar{\imath}$ Zādspram just after the narration of the myth of Tištar (see GignOUX/TAFAZZOLI 1993, P. 42-45). 
the equation between the Zoroastrian divinity and the Manichaean one, as already noted by M. BOYCE. ${ }^{36}$ But, Satauuaēsa was a masculine yazata-, and his transfer to a female cannot be due only to the collapse of the gender system in Middle Iranian; also the direct opposition of this astral divinity with the more prominent image of Anāhīd, has to be deeply considered. Although Anāhīd appeared here in her planetary aspect, which was demonized, so that such a negative role was sharply separated from that of the Mazdean goddess, in any case the secular identification with the Planet Venus (Ištar) preserved some of the archaic characters of this remarkable divinity. We must recall that the denomination of the planets in Iran strictly followed the prominent model of the Babylonian tradition, and that the planet Venus was given this designation because it was earlier associated with Ištar. In this respect the Greeks (with Aphrodítēs) and the Iranians (with Anāhīd) adopted a common pattern. ${ }^{37}$ Only in later times, did the Zoroastrian clergy introduce a dualistic reassessment of the recently well developed astrological art, which was based on Hellenistic traditions and Aristotelian and Ptolemaic parameters, although with a patent influence deriving from the Mesopotamian and, in some aspects, also Egyptian, astral divination. Thus, the positive influence on the sublunar world was attributed only to the stars and the Zodiacal constellations (plus the Luminaries, of course), as it was already in Avestan sources (but outside of any strict astrological model), where the stars were normally regarded as the bringers of rains and symbols of the cosmic order. In this way, in Iranian Late Antiquity, the five planets, apparently unknown in Avestan, were demonized and invested with all the negative influences affecting human beings. In other words, they inherited the hostile role played in the framework of Avestan uranography by the Pairikās or 'starred-worms', i.e. the falling stars. Thus, the planets, although they had earlier been given the proper names of prominent divinities, came to be demonized, but, because of the long and current use, their denominations were not changed. This explains why we have a planetary demon called Ohrmazd (Jupiter), whose name is the same as that of the highest Mazdean divinity, who corresponded exactly to Marduk (= Jupiter). In their own turn, the Manichaeans demonized not only the planets, ${ }^{38}$ but also stars and constellations; only the two Luminaries, the Sun and the Moon, were exempted, although this radical process of demonization of the astral beings shows some contradictions. ${ }^{39}$ One, and among the most relevant ones, is exactly that of Sadwēs. It is probable that, particularly in the Parthian Manichaean framework, the positive role of Satauuaēsa was separated from that of a proper star, and that his association with Anāhīd determined his equation with the Maiden of Light,

36 1951, p. 908, n.3, 910.

37 PANAINO 1993; 1995, passim.

38 When sources refer to seven planets, the additional two were not the Sun and the Moon, but the lunar knots; see SUndermann 1973, p. 45, n. 13; PANAINO 1997.

39 See PANAinO 1997, pp. 268-273. 
whose astral function is in any case evident, although, in the Manichaean context, it was no longer properly that of a star as such.

The connections of Sadwēs with Tištar (Av. Tištriia) and also with Mihr

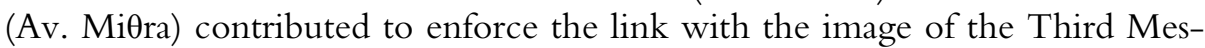
senger. In fact, Sadwēs, as a minor celestial actor, was much more transformable and adaptable to a new framework such as the Manichaean one. Such a mythological transfiguration would not been possible with Tištar, whose role was more important and whose identity was inseparable from that of a prominent astral masculine divinity. Contrariwise, in Avestan, Satauuaēsa, although he operates like a star, apparently is never called stär-; it is only in the Pahlavi sources that Sadwès is undoubtedly presented as one of the axtarān 'stars'. Furthermore, we must note that a potentially fitting equation of the Maiden of Light directly with Anāhīd, as postulated by CUMONT, ${ }^{40}$ would have been too charged with the overwhelming importance of this female Mazdean divinity, in particular in the framework of Iranian kingship, and made more difficult by her reversed negativization in the astrological context. ${ }^{41}$ In fact, the identification of Venus with Anāhīd was current not only in Mazdean astronomy and astrology, but also in the Manichaean tradition, which, accepted an earlier stabilized pattern. ${ }^{42}$ Thus, the transfer of characteristics by Anāhīd, taken as a divinity, to Sadwēs, maintained and adapted as an astral divinity but no longer regarded as a proper star as in the Zoroastrian tradition, took place via the direct confrontation between Venus and the General of the Southern stars.

The present discussion gives to me the opportunity to touch, at least in brief, the problem of the relation between the Maiden of Light and the Twelve Maidens. We know that both are connected, particularly in the Coptic tradition, with the Third Messenger, but also that both are mentioned with relation to the myth of the seduction of the Archons. If it is impossible to state that they are the same image and figure, an oversimplistic solution, in my opinion the relation between them is strongly functional. The feminized Sadwēs, as an alter ego deguisé of Anāhīd, is a seducer, who operates in heavens, moving around and producing clouds and rains thanks to the light emitted by the demons. Although Sadwès is no longer clearly identifiable as a star in the Manichaean context, she behaves as an astral transfiguration, which paradoxically results in the more similar (because of her turning around) image of a planet (i.e. Venus), although not demonized. The indefiniteness of the astral identity of Sadwēs takes advantage of a kind of ambiguity, in which this bright Maiden is not a precise astral body, although she moves in the celestial dimension and seduces the Archons. The movement of the Maiden can be imaged as occurring throughout the, now demonized, twelve Zodiacal constellations, of

40 1908, pp. 64-68; cf. BOYCE 1951, p. 909.

41 GNOLI 2009, pp. 143-145, 150-153; PANAINO 2009a.

42 PANAino 1995, p. 69, n. 40. See also my article "Planets" in the web edition of the Encyclopedia Iranica. 
which the Twelve Maidens are only a symbolic transfiguration. For instance, as M. BOYCE ${ }^{43}$ too thought against the opinion of DE MENASCE, ${ }^{44}$ the narration of the rain-myth, contained in the anti-Manichaean chapter XVI of the Pahlavi-Pāzand apologetic treatise Škand Gumānīg Wizār, is doubtless "closely connected with that of the seduction of the Archons". In paragraphs $28-37,{ }^{45}$ this source clearly states that rain is the seed of the Mazandaran, the demons tied to the sphere; the light that they had previously eaten can now be liberated thanks to a particular stratagem. Thus, the 'Twelve Glorious Daughters of Zurwān' (dvāzdaha Xvarīgq Duxtarq $i$ Zurvąn ${ }^{46}$ provoke concupiscence and sexual excitation in the Mazdandarān demons, ${ }^{47}$ who ejaculate light through their own semen, which, falling on earth, makes the trees, plants and grains grow. The twelve Maidens are not the single Maiden of Light, but their role in this case is the same. The equation between her and Sadwēs, originally a star but also a transfiguration of the planet Venus (Anāhīd), permitted a new adaptation of this myth. Thus, the Twelve Maidens could represent the power of the Zodiacal constellations (formally demonized in Manichaeism), in which the Maiden of Light, equated to Sadwēs-Anāhīd (i.e. to a star and a planet, both demonized in this tradition), appears.

But there is another remarkable fact, which has not yet been fully underlined, which demonstrates that the original stellar role of Satauuaēsa/Sadwēs was really known by Manichaeans and, thus, adapted to their mythology. The role played by Sadwēs as the General of the South in the astral battle against the planets was not per se significant in Manichaeism, because both kinds of astral bodies (fixed stars and planets as well) had apparently been demonized, but the fact that this antidemoniac action was played out in the celestial zone of the South was absolutely significant for a Manichaean observer. In fact, differently from the Mazdean background where the quarter of the demons was the North, the Manichaeans considered the South to be the demoniac cardinal point, and the Southern position attributed to Sadwēs was therefore very fitting to her new function as the seducer of the Archons and producer of rains and clouds, the Maiden of Light.

Although Manichaeism demonized the stars, this process seems to have mostly involved the Zodiac, which was, as we have seen, presented under other allusive forms just as in the case of the Twelve Maidens. With regard to

43 1951, pp. 909-910.

441945 , p. 260 , in the note to par. 14.

45 See DE MENASCE 1945, pp. 253-256; for earlier translations see WeST 1885, p. 245; SALEMANN 1904, p. 19. Cf. also CUMONT 1908, pp. 60-61, n. 1. See also the new translation offered by CERETI in GNOLI 2006, p. 241.

46 See De Menasce 1945, p. 254, 31.

47 It is interesting to note that a demon of Māzan (probably to be connected with the region of Māzandarān) appears in the framework of the rain-production process performed by Tištar, according to ch. XCII of the Dädestān ì Dēnīg (see GIGNOUX 1998, p. 391). 
the so called extra galactic stars, i.e. to the stars belonging to the Milky Way, which, to a certain extent is included in the Column of Light, such a demonization is not at all clear, and probably, as I have already suggested in earlier times, ${ }^{48}$ it was not really carried out. For instance, the General commanding the stellar zone outside of the ecliptic was called in Pahlavi Mazdean sources the Farreh $\bar{i}$ Dén or, as HENNING wrote, ${ }^{49}$ 'the Tyche of the Religion', which was probably associated with the Milky Way or the galactic sphere. The same divinity is known also in Manichaean Middle Persian, Parthian and Sogdian sources respectively as Farrah $\bar{\imath} d \bar{e} n$ [frhh y dyn], ${ }^{50}$ Dēn Farrah [dyn frh $\underline{\text { ] }},{ }^{51} \delta \bar{e} n \bar{i}$-farn or $\delta \bar{e} n-m a z d a y a z n \beta a \gamma i,{ }^{52}$ while in Man. Uigur documents it was named Nom$q u t i{ }^{53}$ In the Manichaean framework she embodies, as in the Zoroastrian tradition, the Church, but represents the 'Nous' too. ${ }^{54}$ This and other examples show that Sadwēs, as a non-Zodiacal star, was probably considered to be of different nature and, thus, not subjected to the demonization we would have expected.

\section{Abbreviations}

BSOAS Bulletin of the School of Oriental and African Studies.

JRAS Journal of the Royal Asiatic Society.

SP Selected Papers (see HenNing 1977).

SPAW Sitzungsberichte der Preußischen Akademie der Wissenschaften, Berlin.

\section{Bibliography}

ANDreas, Friedrich CARl / Walter Bruno Henning (1932): Mitteliranische Manichaica aus Chinesisch-Turkestan, I, Berlin, SPAW, 10, pp. 173-222 [= 1977 $(S P)$, I: $1-48]$.

Bombaci, Alessio (1965): Qutluy bolzun! A Contribution to the history of the concept of 'fortune' among the Turks (Part one). In: Ural-Altaische Jahrbücher 36, pp. 284-291.

48 PANAinO 1997, pp. 270-273.

49 1942, p. 240.

50 SundermanN 1979, p. 102, 132, n. 237; DURKIN-MEISTERERNST 2004, p. 151.

51 SundERMANN 1979, p. 102, 132, n. 238; DURKIN-MEISTERERNST 2004, pp. 154155.

52 See again HeNNING 1942, p. 240, n. 3, where $\delta \bar{e} n-m a z d a y a z n$ Bayi is mentioned with reference to $\mathrm{M} 140$, a source in which the role of the Maiden of Light in the production of rains and clouds is attested (see BoyCE 1951, p. 909). Cf. SUNDERMANN 1979, p. 102, 132, n. 239.

53 About qut see BOMBACI $(1965 ; 1966)$ and GNOLI (1982). Cf. HenNing 1942, p. 240.

54 SundermanN 1979, p. 102, 132, n. 236. 
Bombaci, Alessio (1966): Qutluy bolzun! (Part two). In: Ural-Altaische Jahrbücher 38, pp. 13-44.

Boyce, Mary (1951): Sadwēs and Pēsūs. In: BSOAS 13/4, pp. 908-915.

BOyCE, MARy (1960): A Catalogue of the Iranian Manuscripts in Manichean Script in the German Turfan Collection, Berlin (Deutsche Akademie der Wissenschaften zu Berlin. Institut für Orientforschung. Veröffentlichung Nr. 43).

Boyce, Mary (1975): A Reader in Manichaean Middle Persian and Parthian. Texts with notes, Téhéran/Liège (Acta Iranica 9).

BRUnNeR, CHRISTOPHER J. (1987): Astrology and Astronomy in Iran. ii. Astronomy and Astrology in the Sasanian period. In: EHSAN YARSHATER (ed.), Encyclopadia Iranica, II, 8, London/New York, pp. 862-868.

Cereti, Carlo G. (2006): Testi Medio-Persiani. In: Gherardo GnOli / Andrea PIRAS (eds.), Il Manicheismo. Vol. II. Il mito e la dottrina. I testi copti e la polemica antimanichea, Milano, pp. 235-248.

Cumont, Franz (1908): Recherches sur le Manichéisme. I. La Cosmogonie manichéenne d'après Théodore Bar Khôni, Bruxelles.

Demaria, SERENA (1998): I capitoli LXIX e LXX dei Kephalaia copti manichei. Traduzione e commento, Imola (Archeologia e Storia della Civiltà Egiziana e del Vicino Oriente Antico, Materiali e Studi 3).

Durkin-Meisterernst, DeSMOND (2004): Dictionary of Manichaean Texts. Vol. III. Texts from Central Asia and China. Part 1. Dictionary of Manichaean Middle Persian and Parthian, Turnhout (Corpus Fontium Manichaeorum, Subsidia).

GARDNER, IAIN (1995): The Kephalaia of the Teacher. The Edited Coptic Manichaean Texts in Translation with Commentary, Leiden.

Gershevitch, Ilya (1967): The Avestan Hymn to Mithra, Cambridge.

Gignoux, Philippe (1998): Le méchanisme de la pluie entre le mythe et l'expérimentation (Dādestān ì Dēnīg 92). In: Iranica Antiqua 23, pp. 385-392.

Gignoux, Philippe / Ahmad Tafazzoli (1993): Anthologie de Zādspram. Édition critique du texte pehlevi traduit et commenté, Paris.

Gnoli, Gherardo (1982): 'Qut' e le montagne. In: Aldo Gallotta / Ugo MArazzi (eds.), Studia Turcologica Memoriae Alexii Bombaci Dicata, Istituto Universitario Orientale, Napoli, pp. 251-261.

GNOLI, GHERARDo (2009): Some Notes upon the Religious Significance of the Rabatak Inscription. In: WeRnER SUNDERMANN / ALMUT Hintze / FRANÇOIS DE BloIS (eds.), Exegisti Monumenta. Festschrift in honour of Nicholas Sims-Williams, Wiesbaden, pp. 141-159.

HenNing, Walter BRuno (1942): An Astronomical Chapter of the Bundahishn. In: JRAS, pp. 229-248 [= 1977 (SP), II, pp. 95-114].

Henning, Walter Bruno (1948): A Sogdian fragment of the Manichaean Cosmogony. In: BSOAS, pp. 306-318 [= 1977 (SP), II, pp. 301-313).

Henning, Walter Bruno (1977): Selected Papers, I-II. Téhéran/Liège (Acta Iranica 14-15).

LidZBARSki, MARK (1925): Ginzā. Der Schatz oder das Grosse Buch der Mandäer, Göttingen/Leipzig. 
MACKenZIE, DAVID NeIL (1964): Zoroastrian Astrology in the Bundahišn. In: BSOAS 27, pp. 511-529.

Malandra, William WarRen (1971): The Fravaši Yašt; Introduction, Text, Translation and Commentary. A Dissertation in Oriental Studies presented to the Faculty of the Graduate School of Arts and Sciences of the University of Pennsylvania [...]. Authorized facsimile. University Microfilms International (1981). Ann Arbor, Michigan/London.

MENASCE, JEAN DE (1945): Une apologétique mazdéenne du IX siècle. Škand-GumānīkVičăr, la solution décisive des doutes, Fribourg-en-Suisse.

Pakzad, Fazlollah (2005): Bundahišn. Zoroastrische Kosmogonie und Kosmologie. Band I. Kritische Edition, Tehran.

Panaino, Antonio (1990): Tištrya. Part I. The Avestan Hymn to Sirius, Roma (Serie Orientale Roma LXVIII, 1).

PANAino, Antonio (1993): Considerazioni sul lessico astronomico-astrologico medio-persiano. In: Lingue e Culture in Contatto nel Mondo Antico e Altomedievale. Atti dell' VIII Convegno Internazionale dei Linguisti, tenuto a Milano nei giorni 10-12 Settembre 1992, Brescia, pp. 417-433.

Panaino, Antonio (1995): Tistrya. Part II. The Iranian Myth of the star Sirius, Roma (Serie Orientale Roma LXVIII, 2).

PANAino, ANTONIO (1996): (Av.) Dužyāirya-, (O.P.) dušiyāara-. In: EHSAN YARSHATER (ed.), Encyclopcedia Iranica, Vol. VI,^ Costa Mesa, California, pp. 615-616.

PANAino, ANTONiO (1997): Visione della volta celeste e Astrologia nel Manicheismo. In: Luigi Cirillo / Aloïs van Tongerloo (eds.), Atti del Terzo Congresso Internazionale di Studi: "Manicheismo e Oriente Cristiano Antico». Arcavacata di Rende Amantea, 31 August - 5 September, Lovanii/Neapoli, pp. 249-295.

Panaino, Antonio (1998): Tessere il cielo. Considerazioni sulle Tavole astronomiche, gli Oroscopi e la Dottrina dei Legamenti tra Induismo, Zoroastrismo e Mandeismo, Roma (Serie Orientale Roma LXXIX).

Panaino, Antonio (1999): The Cardinal Asterisms in the Sasanian Uranography. In: RikA Gyselen (ed.), La Science des cieux. Sages, mages et astrologues, Bures-surYvette (Res Orientales XII), pp. 183-190.

PANAINO, ANTONIO (2005): Yt. 8, 8: stārō karamå̄ o stārō.karamåa ? «Stelle infuocate” o "Stelle-verme»? In: GÜNTER SCHWEIGER (ed.), Indogermanica. Festschrift Gert Klingenschmidt. Indische, iranische und indogermanische Studien dem Verehrten Jubilar dargebracht zu seinem fünfundsechzigsten Geburtstag, Taimering (Riekofen), pp. 455-463 (really published in 2006).

PANAino, Antonio (2008): Again about $\alpha$ Cygni in the Sasanian Astronomical Tradition. In: Zohreh Zarshenas / VIDA NADDAF (eds.), Papers in Honour of Professor B. Gharib, Tehran, pp. 33-39.

PANAino, ANTONio (2009a): The Bactrian Royal Title $\beta \alpha \gamma[\eta]-\zeta v o \gamma_{0} / \beta \alpha \gamma o-\eta \eta \zeta v o \gamma o$ and the Kušān Dynastic Cult. In: Werner SundermanN / Almut Hintze / FRANÇOIS DE BLOIS (eds.), Exegisti Monumenta. Festschrift in honour of Nicholas Sims-Williams, Wiesbaden, pp. 331-346.

Panaino, Antonio (2009b): Sasanian Astronomy and Astrology in the Contribution of David Pingree. In: Gherardo Gnoli / Antonio PAnaino (eds.), Kayd. 
Studies in History of Mathematics, Astronomy and Astrology in memory of David Pingree, Roma (Serie Orientale Roma CII), pp. 73-103.

PINGREE, DAVID (1983): Astrology and Astronomy in Iran. i. History of Astronomy in Iran, pp. 858-862. iii. Astrology in Islamic Times, pp. 868-871. In: EHSAN YARSHATER (ed.), Encyclopadia Iranica, II, 8. London/New York.

Polotsky, Hans JaKoB / AleXANDer BÖHLIG (1940): Kephalaia. Manichäische Handschriften der Staatlichen Museen Berlin. Band I. 1. Hälfte (Lieferung 1-10). Mit einem Beitrag von HugO IBSCHER, Stuttgart.

Riggi, Calogero (1967): Epifanio contro Mani. Revisione critica, traduzione italiana e commento storico del Panarion di Epifanio. Haer. LXVI, Roma.

SCHLERATH, BerNFried (1968): Awesta-Wörterbuch. Vorarbeiten II. Konkordanz, Wiesbaden.

SalemanN, Carl (1904): Ein Bruchstük Manichaeischen Schrifttums im Asiatischen Museum (mit einem Facsimile). In: Mémoires de l'Académie Impériale des Sciences de St.-Pétersbourg, 6, 6 (VIII ${ }^{\text {e }}$ Série), pp. 1-26.

SUnDERMANN, WeRner (1973): Mittelpersische und parthische kosmogonische und Parabeltexte der Manichäer. Mit einigen Bemerkungen zu Motiven der Parabeltexte von FR. GEISSLER, Berlin (Berliner Turfantexte IV).

SUNDERMANN, WeRnER (1979): Namen von Göttern, Dämonen und Menschen in iranischen Versionen des manichäischen Mythos. In: Altorientalische Forschungen 6, pp. 95-133.

Sundermann, Werner (2001): Manichaica Iranica. Ausgewählte Schriften von Werner Sundermann. Herausgegeben von Christiane ReCK, DieTER WeBER, Claudia Leurini, Antonio PAnaino, Roma (Serie Orientale Roma LXXXIX, 1, 2).

VAn Lindt, Paul (1992): The Names of Manichaean Mythological Figures. A Comparative Study on Terminology in the Coptic Sources, Wiesbaden (Studies in Oriental Religions 26).

West, Edward William W. (1885): Pahlavi Texts. Part III, Oxford (Sacred Books of the East 24).

WolfF, FRITZ (1910): Avesta, die heiligen Bücher der Parsen, Leipzig. 
